\title{
The Effect of Nutritional Education Using Cognitive Approaches and Psychomotor Approaches on Fruit and Vegetable Consumption Behavior in Children
}

\author{
Fritria Dwi Anggraini*(D), Fauziyatun Nisa (D), Siti Nur Hasina (D), Annif Munjidah(D) \\ Department of Nursing and Midwifery, Universitas Nahdlatul Ulama Surabaya, Surabaya, Indonesia
}

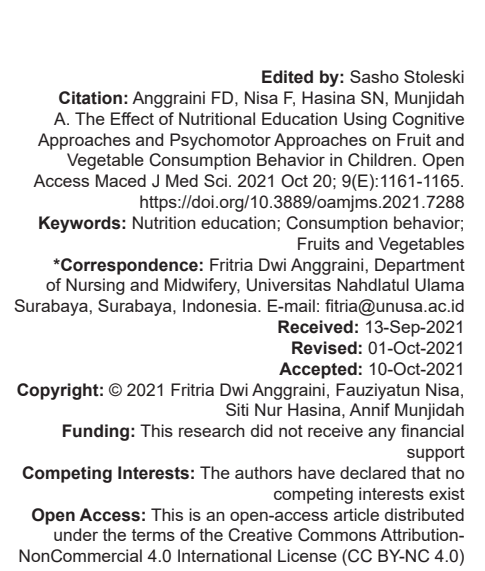

\section{Introduction}

One of the problems related to eating behavior found in children less than 5 years old is the lack of fruit and vegetable consumption. Hermina and Prihatini's (2016) study revealed that the toddler age group consumes $79.4 \mathrm{~g}$ of fruit and vegetables per person per day, even though the WHO recommends the consumption of fruits and vegetables for toddlers and school-aged children, which is $300-400 \mathrm{~g}$ or about 3-5 g servings per person per day [1].

Based on Riskesdas data in 2018, people aged $>5$ years consuming less fruit and vegetables by $95.5 \%$, and people aged $>5$ years in East Java consuming less vegetables by $95 \%$. The results of the research by Hermina and Prihatini (2016) aged 0-59 consume less fruit and vegetables by $97.7 \%$. The results of a preliminary survey conducted in one kindergarten of 10 kindergarten students conducted using FORM Q-FFQ (Quantitative Food Frequency), it was found that 9 out of 10 students $(90 \%)$ consumed less vegetables and fruit, 1 student only consumed vegetables and fruit, while the other 9 students consumed less vegetables and fruit. There were several reasons expressed by 4 parents in kindergarten during the interview. One of them said that mothers always motivate children to eat fruits and vegetables, but in fact children still do not want to eat them and parents think it's normal.

Then, the results of interviews with two other parents, they said that they had tried to persuade children to want to eat vegetables and fruit by modifying them, but the children still did not want to eat them. Another student's guardian said that their children often eat fruit and vegetables but not every day.

Factors that influence fruit and vegetable consumption behavior include knowledge, education, availability of fruit and vegetables, mass media, family support, and family income (Nurmaheasy et al., 2015). Efforts that can be made to overcome children who such as to eat fruits and vegetables include counseling, education, and health promotion. One effort to overcome the problem of lack of fruit and vegetable consumption in children is to conduct nutrition education using media to stimulate children to want to eat fruits and vegetables. Nutrition education that will be carried out is using a cognitive approach and a psychomotor approach. The cognitive approach in the form of knowledge is obtained through experiment, 
research, discovery, and observation (Haryadi and Aripin, 2015). The cognitive approach will be carried out using picture story books and puppet shows. Then, the psychomotor approach is an approach in the form of actions and skills such as jumping, running, painting, and so on (Haryadi and Aripin, 2015). The psychomotor approach will be carried out using puzzle media and fruit and vegetable cards). This study aims to determine the effect of nutrition education using a cognitive approach (with picture book media and wayang performance) and a psychomotor approach (with media puzzle and fruit and vegetable cards) on fruit and vegetable consumption behavior in children in TK Unggulan An-Nur Surabaya [2], [3].

\section{Methods}

This study used a study quasi-experimental design, with a pre- and post-test group design. The population of this research is the students of Kindergarten An-Nur Class A, aged 4-5 years as many as 48 respondents. Sampling using method probability sampling with simple random sampling. The research was conducted in An-Nur Jemurwonosari Kindergarten, Wonocolo, Surabaya. The independent variable in this study is nutrition education with a cognitive approach (using puppet show media and picture story books) and psychomotor approach (using puzzle media and fruit and vegetable cards), while the dependent variable is fruit and vegetable consumption behavior of toddlers. Data collection techniques on consumption behavior fruits and vegetables using the SQ-FFQ form. The intervention was given 4 times. Data analysis used the Wilcoxon test.

\section{Research Results}

Research on "The Effect of Nutrition Education Using Cognitive and Psychomotor Approaches on Fruit and Vegetable Consumption Behavior in Toddlers in An-Nur Preferred Kindergarten Surabaya" has been conducted in An-Nur Jemurwonosari Superior Kindergarten with 48 respondents. The results of the research will be described in the description below:

\section{General data}

Based on Table 1, it is known that most (51.5\%) gender in PreEminent Kindergarten An-Nur is female, most $(57.6 \%)$ of her mother's last education is bachelor's degree, and most (60.6\%) family income is more than the UMK.
Table 1: Distribution of gender, mother's last education, and family income

\begin{tabular}{lll}
\hline Variable & Frequency (n) & Percentage \\
\hline Gender & & \\
$\quad$ Male & 16 & 48.5 \\
$\quad$ Female & 17 & 51.5 \\
Education Last & & \\
$\quad$ Senior High School & 14 & 42.4 \\
$\quad$ Undergraduate & 19 & 57.6 \\
Income & & 39.4 \\
$\quad$ <UMK & 13 & 60.6 \\
$\quad>$ MSE & 20 &
\end{tabular}

\section{Special data}

Based on Table 2, fruit and vegetable consumption behavior before partial intervention large $(72.7 \%)$ in the less category, while the behavior of fruit and vegetable consumption after the intervention was almost entirely $(78.8 \%)$ in the good category.

Table 2: Distribution of fruit and vegetable consumption behavior before and after intervention

\begin{tabular}{llllll}
\hline Variable & Category & Frequency $(\mathrm{n})$ & $(\%)$ & Minimum & Maximum \\
\hline Before education & Less & 24 & 72.7 & 49.0 & 178.0 \\
& Good & 9 & 23.3 & & \\
Total & Excess & 0 & 0 & & \\
After education & Less & 33 & 100,0 & & \multirow{2}{*}{446.0} \\
& Good & 26 & 18.2 & 178.0 & \\
Total & Over & 1 & 78.8 & & \\
Source: Primary Data, 2020. & 33 & 3.0 & & \\
\end{tabular}

Based on Table 3, statistical test results using the Wilcoxon test obtained results Asymp. Sig (2tailed) 0.000 , where the value is $<\alpha(\alpha=0.05)$, meaning that there is a significant difference between fruit and vegetable consumption behavior before the intervention and after the intervention using a cognitive approach (illustrated storybook media and wayang performances) and a psychomotor approach (media card fruit vegetables and puzzles).

Table 3: The effect of cognitive and psychomotor approaches on fruit and vegetable consumption behavior

\begin{tabular}{lllll}
\hline Variable & mean & median & Z & Asymp. Sig (2tailed) \\
\hline Before & 168.0 & 124.0 & -4.244 & 0.000 \\
After & 304.0 & 312.0 & & \\
\hline Source: Primary Data, 2020 & & &
\end{tabular}

\section{Discussion}

\section{Distribution of fruit and vegetable consumption behavior before education using media preeminent}

Based on Table 2 shows that of the 33 respondents of An-Nur's Kindergarten, most of the fruit and vegetable consumption behavior before the intervention $(72.7 \%)$ was in the poor category. The lack of fruit and vegetable consumption is influenced by several factors, including maternal education, family income, nutritional knowledge, availability of fruit and vegetables, and family support (Nurmaheasy et al., 2015). 
Based on Table 1, most of the mothers' last education at TK Superior An-Nur (57.6\%) was undergraduates. Education is the main capital in supporting the economy in the family, and education also plays a role in the preparation of food menus in the family. In addition, with higher education, a person's level of knowledge and information will be more, so they tend to choose foodstuffs and consume healthier foods (Putra, 2016) [4].

The results obtained in this study with high maternal education, fruit and vegetable consumption in children is still relatively low. This is in line with research by Nurmahcepat (2015) which states that there is no relationship between mother's education and consumption of fruits and vegetables in children. From the research, it is clear that maternal higher education is needed for a child, because the mother acts as a family educator. This is a form of implementation in the form of mother's support for children to consume vegetables and fruit. Mothers, who always introduce various types of vegetables and fruits to children, always provide information related to the importance of consuming vegetables and fruit in children and always try to persuade children when children refuse to eat vegetables and fruit can stimulate children to increase their consumption of vegetables and fruits to suit their needs. Recommended by the WHO (Afif and Sumarmi, 2017).

In general, someone with higher education generally has a relatively high income. Thus, the fulfillment of food ingredients in the family will be fulfilled, including fruits and vegetables. Vice versa, low education will affect family income, so it will also affect the fulfillment of needs in the family including the fulfillment of fruits and vegetables.

Based on Table 1, most of the family income $(60.6 \%)$ is more than the UMK. A high level of family income will tend to be followed by a high amount and type of food consumed, including the fulfillment of fruits and vegetables in the family. The high family income will affect the consumption of various types of food. According to Nurmaheasy et al (2015) the work of parents is a source of income for the family, which can meet physical and psychological needs, and there is a significant relationship between family income and the provision of vegetables and fruit in the family.

In this study, the level of family income is high; the consumption of fruit and vegetables in children is still relatively low. This is in line with Putra (2016)'s research which states that there is no significant relationship between family income and fruit and vegetable consumption.

The lack of fruit and vegetable consumption before the intervention was also in line with Bestari's research (2015), and also the research of desi et al (2018) which stated that the lack of fruit and vegetable consumption was 5.18 before the intervention and 4.64 in children before the intervention [5], [6].

\section{Distribution of fruit and vegetable consumption behavior after education using media}

Based on Table 2 shows that of the 33 respondents of An-Nur's PreEminent Kindergarten, almost all of them (78.8\%) were in the good category after the intervention. There was an increase in fruit and vegetable consumption before and after the intervention.

This is presumably the increased consumption of fruits and vegetables in children after the intervention using picture story books, puppet shows, fruit and vegetable cards, and puzzles. In Bestari's research (2015) which states an increase in fruit and vegetable consumption after an intervention using picture story books in Paud Cemara, Semarang. In addition, this study was also supported by Desi et al. (2018) which stated that there was an increase in fruit consumption by 15.00 after the intervention and vegetables by 10.85 after the intervention through puppet games.

Changes in the average value of fruit and vegetable consumption in children before the intervention and after the intervention were also influenced by parents in providing fruit and vegetables at home. This can be seen from the results of filling out the FFQ given to the parents of each child with more variety of fruits and vegetables than before the intervention. In addition, parental support and motivation is very important so that children always consume fruits and vegetables and do not become less in consuming fruits and vegetables.

\section{The effect of nutrition education using cognitive and psychomotor approaches on fruit and vegetable consumption behavior the}

Results of the research on fruit and vegetable consumption behavior of toddlers using a cognitive approach (pictorial storybook media and wayang show media) and a psychomotor approach (media puzzle and fruit vegetable cards) before the intervention and after the intervention. Intervention increases. The results of statistical analysis using the Wilcoxon test showed that the $p$-value was 0.000 where the value was $\leq 0.05$, which indicated that there was a significant difference between fruit and vegetable consumption before and after the intervention. This study is in line with research conducted by Desi et al. (2018) which stated that there was a significant effect of fruit and vegetable consumption before the intervention and after the intervention using puppet games $(p=0.000)$.

The cognitive approach is a subject related to cognition whose ultimate goal is knowledge. In this study, the cognitive approach uses picture story media and wayang performances. Picture story media was chosen because it is very effective in telling the types of fruits and vegetables and their contents. Because besides listening to the stories that are read, they can 
also see directly the pictures and shapes of the fruits and vegetables that are told, thus it is easier for children to understand and understand the types of fruits and vegetables that are around them, so that they also want to eat them. Furthermore, the media used in the cognitive approach is wayang performances. Puppets are unique, funny, creative and traditional as a fun play medium for children while introducing their own nation's traditions from an early age. Puppet media can help develop children's imagination and bring it to abstract concepts (Ngadino, 2009). The puppet show that was performed at the time of the intervention was a story about the importance of consuming fruits and vegetables and the impact on health if they did not consume them. With wayang performances, besides they are actively listening, they will better understand the content of the story that is read. Thus, they will be fonder of consuming fruits and vegetables so they are not affected by negative impacts that endanger health.

The psychomotor approach is defined as a physical activity related to mental and psychological processes whose ultimate goal is in the form of actions and skills (Haryadi and Aripin, 2015). In this study, the media used in the psychomotor approach were puzzles and fruit and vegetable cards. Puzzle is a game that requires accuracy and concentration, because it must arrange a piece of the image into a complete and complete form. Puzzles are games that have educational value for children because they can learn to understand the concepts of shape, color, size, and number (Demitri, 2015). The puzzle used is a puzzle with pictures of fruits and vegetables where students have to put together a puzzle and answer what the content of the fruit or vegetable is. Thus, the child will remember the good content for the health of the fruits and vegetables that will be consumed. Furthermore, the media used in the psychomotor approach is fruit and vegetable cards. Card games are one of the games that toddlers like to play. In this study, students are expected to be able to arrange fruit and vegetable cards according to their benefits. Thus, the child will remember the benefits of fruits and vegetables that will be consumed.

The effect of the intervention using a cognitive approach (illustrated storybook media and wayang show media) and a psychomotor approach (media puzzle and fruit vegetable cards) on children does not only affect fruit and vegetable consumption, but also on respondents' knowledge. Before the intervention, respondents could only answer a few types of fruits and vegetables. However, after being given intervention, respondents were more active in answering questions after hearing the story and were active in playing puzzles and fruit and vegetable cards. This is in accordance with the desired educational target after the intervention using picture story books, puppet games, puzzle media, and fruit and vegetable card media.

Knowledge is the result of knowing and it will happen after someone interacts with a certain object.
Therefore, knowledge is a very important domain in shaping one's behavior.

\section{Conclusion}

Based on the description that has been put forward, the following conclusions can be drawn:

1. Consumption of fruits and vegetables in An-Nur Superior Kindergarten before nutrition education using picture story books, puppet shows, puzzles, and fruit and vegetable cards is mostly in the category not enough

2. Consumption of fruit and vegetables in An-Nur's Superior Kindergarten after nutrition education was carried out using picture story books, puppet shows, puzzles, and fruit and vegetable cards was mostly in the good category

3. There is a significant difference in the consumption of fruits and vegetables in students at the An-Nur Superior Kindergarten

4. There is a significant effect of nutrition education using picture story books, puppet shows, puzzles, and fruit and vegetable cards on students at An-Nur Jemursari-Wonocolo Pre-primary Kindergarten.

\section{Suggestions}

1. For the An-Nur Pre-primary Kindergarten school, it is better to require students to bring lunch from home which has fruit and vegetables on the menu every day, so that children are always exposed to fruits and vegetables every day

2. For the parents should always pay attention to the consumption of children's food, especially vegetables and fruit

3. Nutrition education using picture story books, puppet shows, puzzles, and fruit and vegetable cards for students at the An-Nur JemursariWonocolo Pre-primary Kindergarten should be accompanied by commitment from parents and teachers to increase children's motivation in consuming fruits and vegetables.

\section{References}

1. Afif PA, Sumarmi S. The role of mothers as educators and consumption of fruits and vegetables for children. Amerta 
Nutrition. 2017 Oct 23;1(3):236-42.

2. RDA. The Recommended Nutritional Adequacy Rate for the Indonesian Nation. Attachment to Regulation of the Minister of Health of the Republic of Indonesia N0. 75; 2012.

3. Bestari GS, Pramono A. The effect of nutrition education using picture storybook media on changes in children's fruit and vegetable consumption in early childhood education. J Nutr Coll. 2014;3(4):918-24.

PMid:30345939

4. Demitri A. The Effect of Nutrition Education about a Balanced Diet through Puzzle Games and Animated Images towards Increasing Knowledge of Elementary School Children in Medan City. In: Visual Communication Design Study Program: Faculty of Computer Science, Dian Niswantoro University; 2015.

5. Desi BM, Ginting M. Nutrition education through puppet games on increasing fruit and vegetable consumption. J Health Vocational. 2018 4(1):23.

6. Destiyani L. The Effect of Nutrition Education Using Finger Puppets Media on Fruit and Vegetable Consumption in Group a Children in the State Kindergarten of Pembina West Pontianak. PAUD Undergraduate Study Programs: Faculty of Educational Sciences, University of Muhammadiyah Ponti Anak; 2015.

7. Fadhilah D, Hartini NS, Gunawan IA. The Effectiveness of Counseling about Vegetables Using the Media Vegetable Cards on Increasing Knowledge of Elementary School Students. Yogyakarta: Nutrition Department Poltekkes Kemenkes Yogyakarta; 2017.
8. Febry AB, Pujiastuti N, Fajar I. Nutritional Sciences for Health Practitioners. Yogyakarta: GrahaScience; 2013.

9. Hermina, Prihatini S. Fruit and Vegetable consumption Overview Population Indonesia in the Context of Balanced Nutrition: Advanced Analysis of Individual Food consumption Survey (SKMI) in 2014, the Health Research Bulletin, September; 2016.

10. Haryadi T, Aripin. Training the Cognitive, Affective, and Psychomotor Intelligence of Elementary School Children through the Design of the Simulation Game "Warungku". Visual Communication Design Study Program: Faculty of Computer Science, Dian Niswantoro University; 2015.

11. Kurniawati T, Wahono, Sa'ida N. Patterns of Fruit and vegetable consumption in early childhood as an effort to combat cancer. J Early Childhood Early Childhood Educ. 2017;33:3.

12. No. Ngadino. Introduction Learning Media Development. Surakarta: Teacher Professional Education FKIP UNS; 2009.

13. Nurmaheasy KN, Aruben R, Suyatno. Factors Affecting Consumption of Eating Fruits and Vegetables in Pre-School Children in PAUD TK SAPTA PRASETYA, Semarang City. Vol. 3. Faculty of Public Health: Diponegoro University; 2015.

14. Putra WK. Factors Associated with Fruit and Vegetable Consumption of Elementary School Children. Essay. Semarang: Department of Public Health, State University of Semarang; 2016.

15. Basic Health Research (Riskesdas). Indonesian Ministry of Health Research and Development Agency in 2018; 2018. 